\title{
EFEKTIVITAS PELAKSANAAN AKUNTANSI PADA UMKM DI KOTA MAKASSAR
}

\author{
Syamsu Alam \\ Dosen Fakultas Ekonomi Universitas Muslim Indonesia, \\ e-mail:ancu_alam@yahoo.com
}

\begin{abstract}
ABSTRAK
Penelitian bertujuan untuk untuk mengetahui pelaksanaan akuntansi pada UMKM di Kota Makassar dan pengaruh tingkat pendidikan pemilik dan pengalaman usaha terhadap efektivitas pelaksanaan akuntansi pada UMKM di Kota Makassar. Diharapkan penelitian ini bermanfaat bagi para pelaku UMKM dan memberikan informasi mengenai pentingnya akuntansi dalam kelangsungan usaha mereka. Bagi akademik, dapat dijadikan sebagai bahan bacaan dan pengayaan mengenai efektivitas pelaksanaan akuntansi pada UMKM.

Penelitian ini dilakukan di Pusat Grosir Pasar Butung Makassar. Yang menjadi objek dalam penelitian ini adalah efektivitas pelaksanaan akuntansi, pendidikan pemilik dan pengalaman usaha. Populasi penelitian ini adalah keseluruhan Usaha Kecil dan Menengah (UMKM) di Pasar Butung Makassar yang berjumlah 800 UMKM. Penentuan jumlah sampel dalam penelitian ini menggunakan rumus Slovin dan jumlah sampel yang digunakan dalam penelitian ini adalah sebanyak 89 UMKM di Pasar Butung Makassar. Penelitian ini menggunakan data primer dan sekunder, dikumpulkan dengan menggunakan kuesioner dan studi dokumentasi. data diuji validitas, dan reliabilitas. dilakukan uji asumsi klasik sebelum melakukan analisis data. Analisa data menggunakan regresi berganda.

Hasil pengujian hipotesis menunjukan bahwa pendidikan pemilik terhadap efektivitas pelaksanaan akuntansi pada nilai $T_{\text {hitung }}$ sebesar 5,026 dan nilai signifikan sebesar 0,000. Nilai $T_{\text {tabel }}$ dengan menggunakan tingkat signifikansi 0,05 adalah sebesar 1,987 artinya pendidikan pemilik berpengaruh positif dan signifikan terhadap efektivitas pelaksanaan akuntansi. Begitu pula pengalaman usaha terhadap efektivitas pelaksanaan akuntansi pada nilai $T_{\text {hitung }}$ sebesar 0,293 dan nilai signifikan sebesar 0,770. Nilai $T_{\text {tabel }}$ dengan menggunakan tingkat signifikansi 0,05 adalah sebesar 1,987 artinya pengalaman usaha berpengaruh positif dan tidak signifikan terhadap efektvitas pelaksanaan akuntansi.
\end{abstract}

Keyword :Pelaksanaan Akuntansi UMKM, Tingkat Pendidikan, Pengalaman Usaha.

\section{PENDAHULUAN}

Berbisnis tak hanya persoalan mendapatkan uang saja, namun juga mengendalikan dan membelanjakannya perlu pengelolaan yang baik untuk menjamin kelangsungan usaha. Pasar Butung Makassar merupakan pasar bagi masyarakat yang menunjang perekonomian dengan omset yang cukup besar. Persoalan yang dihadapi para pedagang di Pasar Butung Makassar ini, banyak pedagang di merasa omset yang mereka raih cukup besar, namun keuntungan tetap saja tak tersisa di kas usaha. Kondisi ini terjadi karena mereka belum bisa mengatur keuangan dengan baik.

Informasi yang disediakan oleh catatan-catatan akuntansi berguna bagi pengambilan keputusan sehingga dapat meningkatkan pengelolaan perusahaan. 
Informasi-informasi tersebut memungkinkan para pelaku UMKM dapat mengidentifikasi dan memprediksi area-area permasalahan yang mungkin timbul, kemudian mengambil tindakan koreksi tepat waktu.

Menurut Era (2007), menunjukkan bahwa skala usaha, masa memimpin perusahaan dan pelatihan akuntansi yang diikuti pendidikan pemilik berpengaruh signifikan terhadap penyiapan dan penggunaan informasi akuntansi. Holmes dan Nicholls (1988) dalam Muhammad (2009), menyatakan bahwa kemampuan dan keahlian pemilik atau manajer UMKM ditentukan dari pendidikan formal yang pernah ditempuh. Tingkat pendidikan manajer atau pemilik menentukan pemahaman manajer atau pemilik terhadap pentingnya penggunaan informasi akuntansi.

Selanjutnya, Holmes menyatakan bahwa masa manajer memimpin perusahaan atau lamanya seseorang memimpin perusahaan menentukan tingkat pemahaman akan pentingnya akuntansi dalam sebuah perusahaan. Semakin lama usia seseorang memimpin perusahaan, maka akan semakin bertambah kebutuhannya akan berbagai informasi, dan tentunya informasi tersebut hanya bisa didapatkan jika perusahaan menyelenggarakan teknik akuntansi dengan benar.

Efektifnya pelaksanaan akuntansi untuk menghasilkan informasi akuntansi dalam perusahaan dapat menentukan kualitas keputusan yang akan diambil. Semakin efektif pelaksanaan akuntansi dalam menghasilkan informasi akuntansi yang digunakan, semakin baik pula keputusan yang diambil, sehingga memaksimalkan tujuan yang akan dicapai.

Informasi merupakan sumber daya yang penting dalam proses pengelolaan perusahaan guna kelangsungan usaha perusahaan. Informasi tersebut dapat berupa informasi akuntansi keuangan dan informasi manajemen. Keduanya merupakan output dari akuntansi. Penggunaan informasi tersebut dipengaruhi oleh beberapa faktor, yaitu pendidikan manajer dan pengalaman usaha.

Holmes selanjutnya mengklasifikasikan informasi berdasarkan manfaat bagi pemakainya ke dalam tiga jenis, yaitu : (1) statutory accounting information, merupakan informasi yang harus disiapkan sesuai dengan peraturan yang ada; (2) budgetary information, yaitu informasi akuntansi yang disajikan dalam bentuk anggaran yang berguna bagi pihak internal perusahaan dalam perencanaan, penilaian dan pengambilan suatu keputusan; (3) additional accounting information, yaitu informasi akuntansi lainnya yang disiapkan perusahaan guna meningkatkan efektivitas pengambilan keputusan manajer. UKM sebagai salah satu entitas bisnis yang tumbuh pesat di kalangan masyarakat dan mampu menujukkan peran yang sangat berarti dalam perekonomian Indonesia.

Dalam pengembangannya, secara umum UKM menghadapi permasalahan yaitu kurang mampunya untuk berkembang dari sebuah perusahaan kecil menjadi perusahaan besar. Tidak sedikit UKM yang gulung tikar karena tidak mampu menghadapi persaingan dunia bisnis dan imbas dari krisis ekonomi global.

Masalah yang sering dihadapi oleh para pelaku UMKM di Pasar Butung Makassar seperti pemasaran produk, teknologi, pengelolaan keuangan, kualitas sumber daya manusia, dan permodalan. Salah satu masalah yang seringkali terabaikan oleh para pelaku bisnis UMKM di Makassar yaitu mengenai 
pengelolaan keuangan. Dampak diabaikannya pengelolaan keuangan mungkin tidak terlihat secara jelas, namun tanpa adanya pelaksanaan akuntansi yang efektif, usaha dapat saja mengalami kebangkrutan.

Pelaksanaan akuntansi untuk menghasilkan laporan keuangan merupakan hal yang penting bagi UMKM. Keterbatasan pengetahuan pembukuan akuntansi, rumitnya proses akuntansi, dan anggapan bahwa laporan keuangan bukanlah hal yang penting bagi UMKM menjadi alasan bagi UMKM untuk tidak melakukan pembukuan secara akuntansi.

Banyak kasus para UMKM yang tidak melakukan pembukuan dengan benar atau bahkan tidak sama sekali, mengakibatkan mereka juga tidak mengetahui perkembangan usahanya. Terkadang pencatatan yang dilakukan hanya sebatas jumlah pembelian dan penjualan yang terjadi dalam kegiatan operasionalnya. Bentuk UMKM yang didominasi perusahaan perseorangan mengakibatkan kurangnya kebutuhan untuk membuat laporan keuangan yang sesuai standar akuntansi. Bentuk perusahaan perseorangan juga menyebabkan pemisahan keuangan bagi diri pribadi pemilik usaha dengan kegiatan usahanya seringkali juga tidak dilakukan.

Berdasarkan uraian latar belakang di atas, maka rumusan masalah dalam penelitian ini adalah apakah pelaksanaan akuntansi pada UMKM di Makassar telah terlaksana dengan efektif dan apakah tingkat pendidikan pemilik dan pengalaman usaha berpengaruh terhadap efektivitas pelaksanaan akuntansi pada UMKM di Makassar.

Penelitian bertujuan untuk mengetahui mekanismen pelaksanaan akuntansi pada UMKM di Kota Makassar dan untuk mengetahui pengaruh tingkat pendidikan pemilik dan pengalaman usaha terhadap efektivitas pelaksanaan akuntansi pada UMKM di Kota Makassar. Diharapkan penelitian ini bermanfaat bagi para pelaku UMKM mengenai akuntansi pada UMKM dan memberikan informasi mengenai pentingnya akuntansi dalam kelangsungan usaha mereka dan bagi akademik, dapat dijadikan sebagai bahan bacaan dan pengayaan mengenai efektivitas pelaksanaan akuntansi pada UMKM.

Teori entitas (entity theory) memandang entitas sebagai sesuatu yang terpisah dan berbeda dari mereka yang menyediakan modal bagi entitas tersebut. Sederhananya, unit bisnis yang menjadi pusat dari kepentingan akuntansi bukan pemilik. Unit bisnis memiliki sumber daya perusahaan dan bertanggungjawab atas klaim pemilik maupun kreditor (Belkaoui, 2006).

Konsep kesatuan usaha (Suwardjono 2005) menyatakan bahwa perusahaan dianggap sebagai suatu kesatuan atau badan ekonomi yang berdiri sendiri, bertindak atas namanya sendiri dan kedudukannya terpisah dari pemilik atau pihak lain yang menanamkan dana dalam perusahaan dan kesatuan ekonomi tersebut menjadi pusat perhatian atau sudut pandang akuntansi.

Kesatuan usaha (Economic Entity Concept) yang menyatakan bahwa seharusnya entitas (UMKM) harus dianggap sebagai entitas yang berdiri sendiri, terlepas dari pemiliknya. Pemisahan keuangan bagi diri pribadi pemilik usaha dengan kegiatan usaha seharusnya menjadi hal yang wajib untuk dilakukan. Konsep ini penting untuk kelangsungan hidup UMKM sendiri. Pemilik usaha seringkali bingung menentukan keuntungan yang diraih apabila tidak dilakukan 
pemisahan keuangan. Lebih parah lagi terjadi apabila tidak terdapat kejelasan uang yang digunakan untuk kegiatan operasional usaha dengan kegiatan pribadi pemilik usaha.

Tidak dapat dipungkiri, salah satu yang menjadi masalah utama dalam pemisahan keuangan bagi UMKM adalah saat adanya penggunaan barang modal ataupun uang yang berasal dari kegiatan usaha bagi kebutuhan pribadi pemilik (prive). Namun, seringkali prive yang dilakukan oleh pemilik tidak diakui sebagai penarikan modal, hanya sebatas pemakaian pribadi.

Komite Terminologi AICPA (The Committee on Terminology of the American Institute of Certified Public Accountants) mendefinisikan akuntansi sebagai seni pencatatan, penggolongan, dan pengikhtisaran transaksi serta kejadian yang bersifat keuangan dengan cara yang berdaya guna dan dalam bentuk satuan uang, serta interpretasi dari hasil proses tersebut. Accounting Principles Board (APB) statement No. 4 mendefinisikan akuntansi adalah suatu kegiatan jasa. Fungsinya adalah memberikan informasi kuantitatif, terutama yang bersifat keuangan, mengenai suatu entitas ekonomi yang dimaksudkan untuk digunakan dalam pengambilan keputusan ekonomi, sebagai dasar dalam memilih di antara beberapa alternatif.

American Accounting Association mendefinisikan akuntansi sebagai suatu proses pengidentifikasian, pengukuran, dan pengomunikasian informasi ekonomi yang memungkinkan pertimbangan dan pengambilan keputusan yang didasarkan pada informasi terkini oleh pemakai informasi (Arfan, 2011). Secara umum, akuntansi dapat diartikan sebagai sistem informasi yang menyediakan laporan kepada para pemangku kepentingan mengenai aktivitas ekonomi dan kondisi perusahaan.

Usaha Mikro, Kecil dan Menengah (UMKM) merupakan kelompok usaha yang memiliki jumlah yang cukup besar di Indonesia. Definisi untuk masingmasing kelompok usaha tersebut berbeda-beda sebagaimana diungkap dalam Undang-Undang (UU) Nomor 20 tahun 2008. Usaha Mikro adalah usaha produktif milik orang perorangan dan/atau badan usaha perorangan yang memenuhi kriteria usaha mikro sebagaimana diatur dalam Undang-undang ini.

Kriteria UMKM menurut UU No. 20 tahun 2008 digolongkan berdasarkan jumlah aset dan omzet yang dimiliki oleh suatu usaha sebagaimana tampak dalam Tabel 1 berikut ini :

Tabel 1.

Penggolongan Kriteria UMKM

\begin{tabular}{|c|l|l|l|}
\hline \multirow{2}{*}{ No. } & \multirow{2}{*}{ Usaha } & \multicolumn{2}{|c|}{ Kriteria (dalam rupiah) } \\
\cline { 3 - 4 } 1. & Usaha Mikro & Max. 50 jt & \multicolumn{1}{c|}{ Omzet } \\
\hline 2. & Usaha Kecil & $>50$ jt sampai 500jt & $>$ 300jt sampai 2,5 Milyar \\
\hline 3. & Usaha Menengah & $\begin{array}{l}>500 j t \text { sampai 10 } \\
\text { Milyar }\end{array}$ & $\begin{array}{l}>2,5 \text { Milyar sampai 50 } \\
\text { Milyar }\end{array}$ \\
\hline
\end{tabular}

Sumber : www.galeriukm.web.id

Berbagai kemudahan telah ditawarkan pemerintah bagi pelaku usaha UMKM. Namun tak dapat dipungkiri, masih tersembul kendala yang menjadi 
tantangan bagi kemajuan UMKM di Indonesia. Warsono (2010) mengungkapkan beberapa tantangan UMKM di Indonesia, antara lain:

a. Ketiadaan pembagian tugas yang jelas antara bidang administrasi dan operasi. Kebanyakan UMKM dikelola perorangan yang merangkap sebagai pemilik sekaligus pengelola perusahaan, serta memanfaatkan tenaga kerja dari keluarga dan kerabat dekatnya;

b. Rendahnya akses industri kecil terhadap lembaga-lembaga kredit formal sehingga mereka cenderung menggantungkan pembiayaan usahanya dari modal sendiri atau sumber-sumber lain seperti keluarga, kerabat, pedagang perantara bahkan rentenir;

c. Kekurangjelasan status hukum sebagian besar UMKM. Mayoritas UMKM merupakan perusahaan perseorangan yang tidak berakta notaris; 4,7\% tergolong perusahaan perorangan berakta notaris dan hanya $1,7 \%$ yang sudah mempunyai badan hukum seperti misalnya PT, CV, firma atau koperasi.

Pemerintah menaruh perhatian yang tinggi terhadap pengembangan UMKM di Indonesia. Munculnya Kementerian Negara Koperasi dan Usaha Kecil dan Menengah merupakan cerminan keseriusan pemerintah terhadap UMKM. Berdasarkan data Kementerian Koperasi dan Usaha Kecil dan Menengah Warsono (2010), beberapa program unggulan untuk pengembangan UMKM antara lain:

a. Program Kredit Usaha Rakyat (KUR) sebagai agenda prioritas Menteri Negara Koperasi dan UKM. Hal ini dimaksudkan untuk mendorong pengembangan usaha mikro kecil dan menengah serta menggerakkan sektor riil;

b. Kementerian Koperasi dan UKM meminta pelibatan sebagai penilai UKM yang layak mendapat dana program kemitraan dan bina lingkungan BUMN. Dana yang cukup besar (mencapai Rp 1,5 triliun) tersebut ditengarai tidak cukup banyak diserap oleh UKM;

c. Kementerian Negara Koperasi dan UKM tengah mengevaluasi sekitar 400 peraturan daerah (Perda) bermasalah yang dinilai membebani pelaku usaha UMKM. Dari 400 perda yang dievaluasi, sejumlah 63 peraturan telah dibatalkan dan 160 perda sedang dievaluasi. Perda yang paling menonjol untuk dievaluasi adalah yang terkait dengan perijinan.

Perhatian dan kepedulian yang besar dari pemerintah tentu akan mendorong pertumbuhan dan perkembangan UMKM di Indonesia. Seiring pertumbuhan yang semakin maju maka harapan bahwa UMKM akan menjadi soko guru dalam perekonomian Indonesia bukanlah imajinasi semata.

\section{Hipotesis}

\section{Pendidikan Pemilik terhadap Efektivitas Pelaksanaan Akuntansi.}

Kemampuan dan keahlian pemilik atau manajer perusahaan kecil dan menengah saat ini sangat ditentukan oleh pendidikan formal yang pernah ditempuh. Tingkat pendidikan formal yang rendah (tingkat pendidikan sekolah dasar sampai dengan sekolah menengah umum) akan berpengaruh pada rendahnya pelaksanaan akuntansi dibandingkan dengan tingkat pendidikan formal yang tinggi (perguruan tinggi). Ini disebabkan pengajaran akuntansi lebih tinggi diberikan di perguruan tinggi dibandingkan dengan pendidikan yang lebih rendah. 
Kemampuan dan keahlian pemilik atau manajer perusahaan kecil dan menengah sangat ditentukan oleh pendidikan formal yang pernah ditempuh (Murniati, 2002). Tingkat pendidikan formal yang rendah pemilik atau manajer akan rendah penggunaan informasi akuntansi dibandingkan dengan tingkatan pendidikan formal yang tinggi (perguruan tinggi) pemilik atau manajer.

Era (2007), menunjukkan bahwa terdapat pengaruh antara variabel pendidikan pemilik atau manajer terhadap penyiapan dan penggunaan informasi akuntansi perusahaan kecil dan menengah di kabupaten Kudus. Pratiwi (2011) Pengaruh positif antara tingkat pendidikan pemilik, pemahaman teknologi informasi, karakteristik kualitatif laporan keuangan terhadap kebutuhan Standar Akuntansi Keuangan Entitas Tanpa Akuntanbilitas Publik (SAK ETAP) bagi Usaha Kecil dan Menengah (UMKM).

Hipotesis 1 = Diduga pendidikan pemilik berpengaruh negatif terhadap efektivitas pelaksanaan akuntansi pada UMKM di Makassar.

\section{Pengalaman Usaha terhadap Efektivitas Pelaksanaan Akuntansi}

Pelaksanaan pengelolaan perusahaan, pemimpin perusahaan akan banyak memperoleh pengalaman dari berbagai pihak baik dari dalam perusahaan maupun dari luar perusahaan. Masa manajer memimpin perusahaan atau lamanya seseorang memimpin perusahaan akan menentukan tingkat pemahaman akan pentingnya akuntansi dalam sebuah perusahaan. Semakin lama seseorang memimpin perusahaan maka semakin bertambah kebutuhannya akan berbagai informasi, dan tentunya informasi tersebut hanya bisa didapatkan jika perusahaan menyelenggarakan teknik akuntansi secara benar.

Holmes dan Nicholls (1989) menyatakan bahwa pengalaman dalam perusahaan berpengaruh positif terhadap pelaksanaan dan penyiapan informasi akuntansi pada usaha kecil dan menengah. Hasil penelitian mereka menunjukkan bahwa perusahaan yang berdiri selama 10 tahun atau kurang akan menyediakan lebih banyak informasi akuntansi statutori, informasi akuntansi anggaran dan informasi akuntansi tambahan untuk digunakan dalam pengambilan keputusan, berbeda dengan perusahaan yang berdiri selama 11-20 tahun.

Era (2007), juga menunjukkan bahwa terdapat pengaruh positif antara variabel masa memimpin terhadap penyiapan dan penggunaan informasi akuntansi perusahaan kecil dan menengah di kabupaten Kudus. Dewi (2010) Perusahaan yang sudah cukup berkembang dan berpengalaman, karena transaksinya sudah bertambah banyak, maka perusahaan perlu menerapkan sistem akuntansi. Pencatatan yang dilaksanakan secara manual terasa sudah tidak memadai lagi dan hingga perlu penerapan akuntansi sesuai standar akuntansi.

Hipotesis 2 = Diduga pengalaman usaha berpengaruh positif terhadap efektivitas pelakasanaan akuntansi pada UMKM di Makassar.

Dari pengembangan hipotesis diatas maka dapat digambarkan model penelitian sebagai berikut : 


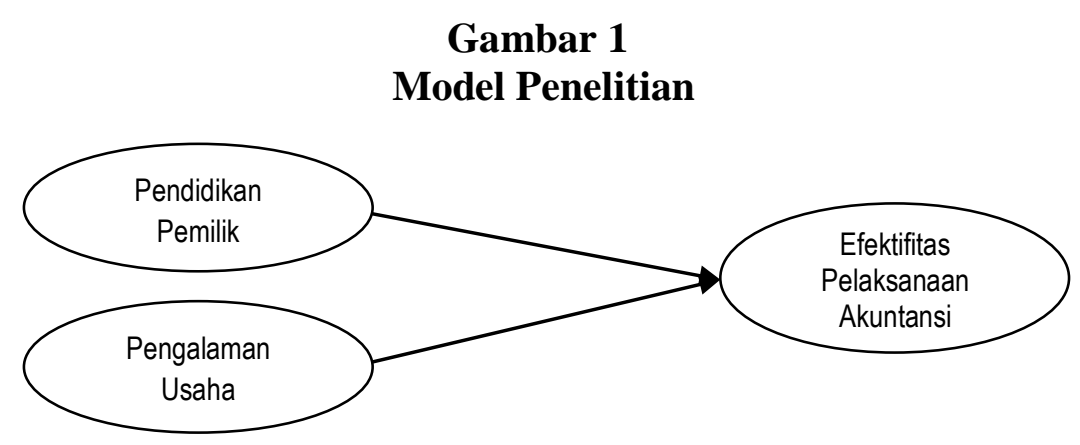

\section{METODE PENELITIAN}

\section{Lokasi dan Waktu Penelitian}

Lokasi dalam penelitian ini adalah Pusat Grosir Pasar Butung Makassar yang beralamat di Jalan Butung, Kelurahan Butung, Kecamatan Wajo, Kota Makassar Sulawesi Selatan. Waktu penelitian dilaksanakan selama kurang lebih 2 (dua) bulan, yaitu bulan Januari - Februari 2017.

\section{Objek Penelitian}

Yang menjadi objek dalam penelitian ini adalah efektivitas pelaksanaan akuntansi, pendidikan pemilik dan pengalaman usaha.

\section{Definisi Operasional Variabel}

Untuk memperjelas pengujian hipotesis yang dikemukakan maka variabelvariabel yang diidentifikasikan dioperasionalisasikan sebagai berikut:

1. Efektivitas Pelaksanaan Akuntansi adalah sebagai alat pengukur tingkat pencapaian atau tingkat keberhasilan dari suatu proses mencatat, mengklasifikasi, meringkas, mengolah, dan menyajikan data, transaksi serta kejadian yang berhubungan dengan keuangan, sehingga dapat digunakan oleh orang yang menggunakannya dengan mudah dimengerti untuk pengambilan suatu keputusan serta tujuan lainnya.

2. Pendidikan Pemilik, akan diukur berdasarkan pendidikan formal yang pernah diikuti sehingga pengukurannya bersifat kontinyu. Pendidikan formal yang dimaksud adalah pendidikan yang diperoleh dibangku sekolah formal antara lain Sekolah Dasar (SD), Sekolah Menengah Pertama (SMP), Sekolah Menengah Umum (SMU) atau yang sederajat, Diploma, Sarjana (SI) dan Pascasarjana (S2).

3. Pengalaman Usaha, diukur mulai dari manajemen menjalankan usaha, sehingga mempersiapkan dan menggunakan informasi akuntansi.

\section{Populasi dan Sampel Penelitian}

Populasi dalam penelitian ini adalah jumlah keseluruhan Usaha Kecil dan Menengah (UMKM) di Pasar Butung Makassar yang berjumlah 800 UMKM. Penentuan jumlah sampel dalam penelitian ini menggunakan rumus Slovin, yang mengatakan bahwa rumus Slovin mempunyai asumsi bahwa populasi berdistribusi normal (Umar, 2007), yaitu: 


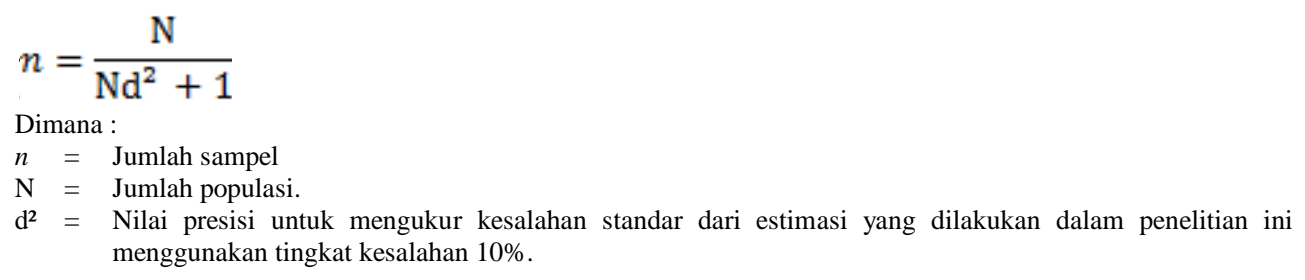

Dengan menggunakan rumus penentuan sampel di atas, jumlah sampel dari UMKM di Pasar Butung Makassar adalah:

$$
\begin{aligned}
n & =\frac{800}{800(0,1)^{2}+1} \\
& =88,88 \text { (dibulatkan } 89 \text { UMKM). }
\end{aligned}
$$

Jumlah sampel yang digunakan dalam penelitian ini adalah sebanyak 89 UMKM di Pasar Butung Makassar.

\section{Metode Pengumpulan Data}

Dalam penelitian ini data yang dibutuhkan adalah berupa data primer dan data sekunder. Data primer dan data sekunder tersebut dikumpulkan dengan teknik pengumpulan data sebagai berikut:

a. Kuesioner. memberikan seperangkat pertanyaan atau pertanyaan tertulis kepada responden untuk dijawab.

b. Studi Dokumentasi. mempelajari berbagai dokumen yang diperoleh langsung dari pelaku UMKM di Pasar Butung Makassar.

\section{Uji Kualitas Data}

1. Uji Validitas, menunjukkan instrumen tersebut mengukur apa yang seharusnya diukur. Dengan kata lain instrumen tersebut dapat mengukur construct sesuai dengan yang diharapkan oleh peneliti. Pendekatan yang digunakan dalam penelitian ini adalah contruct validity yaitu mengukur contruct tertentu, yang artinya apakah suatu instrumen mengukur contruct sesuai dengan yang diharapkan (Indriantoro, Nur, dan Bambang, 2002).

2. Uji Reliabilitas, menunjuk apakah sebuah instrumen dapat mengukur sesuatu yang diukur secara konsisten dari waktu ke waktu. Teknik yang digunakan dalam penelitian ini adalah Alpha Cronbach karena menggunakan jenis data likert/essay. Teknik ini dapat menafsirkan skala yang diukur dengan variabel yang ada.

\section{Penilaian Efektivitas}

Untuk mengetahui seberapa besar efektivitas pelaksanaan akuntansi pada UMKM di Makassar dapat dilihat pada rumus di bawah ini:

Jumlah Skor Kriterium $=$ Skor tertinggi $\times$ jumlah pertanyaan $\times$ jumlah responden Keterangan :

\footnotetext{
Tingkat Persentase Efektivitas $=\frac{a \mathrm{i}}{b \mathrm{i}} \times 100 \%$

Dimana :

$a \mathrm{i}=$ Total skor ke-i

$b \mathrm{i}=$ Jumlah skor kriterium ke-i
} 
Tabel 2.

Tingkat Efektivitas

\begin{tabular}{|l|c|}
\hline \multicolumn{1}{|c|}{ Kategori } & Persentase \\
\hline Sangat Efektif & $80 \%-100 \%$ \\
\hline Efektif & $60 \%-79 \%$ \\
\hline Cukup Efektif & $40 \%-59 \%$ \\
\hline Tidak Efektif & $<40 \%$ \\
\hline \multicolumn{2}{|c|}{ Sumber : Sugiyanto (2005) }
\end{tabular}

\section{Uji Asumsi Klasik}

1. Uji Normalitas, untuk menguji apakah dalam model regresi, variabel dependen dan independen memiliki distribusi normal atau tidak. Untuk model regresi yang baik digunakan data yang terdistribusi normal atau mendekati normal.

2. Uji Autokolerasi, untuk mengetahui ada tidaknya korelasi antara kesalahan pengganggu pada periode $\mathrm{t}$ dengan kesalahan pada periode $\mathrm{t}-1$ (sebelumnya). Adanya autokorelasi dalam regresi dapat diketahui dengan uji Durbin Watson.

3. Uji Multikolinearitas, untuk menguji antara variabel bebas yang satu dengan variabel bebas yang lain dalam model regresi saling berkolerasi linier. Batas tolerance adalah 0,01 dan batas untuk nilai VIF harus kurang dari 10.

4. Uji Heteroskedastisitas, untuk mengetahui ada atau tidaknya penyimpangan asumsi klasik heteroskedastisitas, yaitu adanya ketidaksamaan varian dari residual untuk semua pengamatan pada model regresi. Adanya heteroskedastisitas dapat diketahui dengan menggunakan uji Glesjer dengan menggunakan taraf signifikansi 5\%.

\section{Metode Analisis Data}

Analisa data adalah cara-cara mengolah data yang telah terkumpul kemudian dapat memberikan interpretasi. Hasil pengolahan data ini digunakan untuk menjawab masalah yang telah dirumuskan. Metode analisis yang digunakan dalam penelitian ini adalah metode analisis regresi berganda dengan persamaan sebagai berikut:

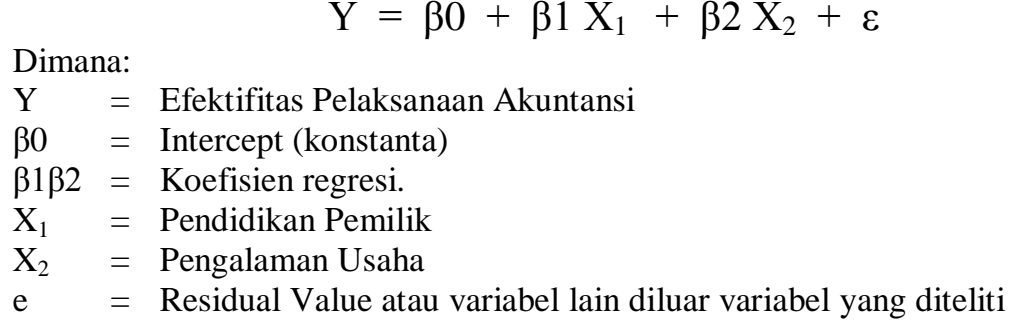

Arti koefisien $\beta$ adalah jika nilai $\beta$ positif $(+)$ hal tersebut menunjukkan hubungan yang searah antara variabel bebas dengan variabel tidak bebas. Dengan kata lain peningkatan/penurunan variabel bebas akan disertai dengan peningkatan/ penurunan variabel tidak bebas. Sedangkan jika nilai $\beta$ negatif (-) hal tersebut menunjukkan hubungan yang berlawanan antara variabel bebas dengan tidak bebas. Setiap peningkatan variabel bebas akan diikuti dengan penurunan variabel 
tidak bebas, dan begitupun sebaliknya. Toleransi kesalahan $(\alpha)$ yang ditetapkan sebesar 5\% dengan signifikansi sebesar 95\%.

\section{Statistik Deskriptif}

Statistik deskriptif digunakan untuk memberikan informasi mengenai karakteristik variabel penelitian dan demografi responden. Statistik deskriptif menjelaskan skala jawaban responden pada setiap variabel yang diukur dari maximum, minimum, rata-rata, dan standar deviasi. Disamping itu juga untuk mengetahui demografi yang terdiri dari kategori, jenis kelamin, tingkat pendidikan, dan sebagainnya (Imam, 2013).

\section{Pengujian Hipotesis}

\section{a. Pengujian hipotesis secara simultan}

Menguji hipotesis tersebut dengan mengunakan statistik uji-F, yaitu dengan membandingkan $F_{\text {hitung }}$ dengan $F_{\text {tabel }}$ pada $\alpha=0,05$ dan derajat bebas $(k)$, (n-k1), dimana $\mathrm{k}$ adalah jumlah variabel independen dengan kriteria keputusan:

Jika $\mathrm{F}_{\text {hitung }} \leq \mathrm{F}_{\text {tabel }}: \mathrm{H}_{0}$ diterima atau $\mathrm{H}_{1}$ ditolak.

Jika $\mathrm{F}_{\text {hitung }}>\mathrm{F}_{\text {tabel }}: \mathrm{H}_{1}$ diterima atau $\mathrm{H}_{0}$ ditolak.

\section{b. Pengujian hipotesis secara parsial}

Untuk menguji pengaruh pendidikan pemilik dan pengalaman usaha terhadap efektivitas pelaksanaan akuntansi pada UMKM adalah sebagai berikut:

Ho : $\beta_{\mathrm{i}} \leq 0$ Pendidikan pemilik $\left(\mathrm{X}_{1}\right)$ dan pengalaman usaha $\left(\mathrm{X}_{2}\right)$ secara parsial tidak berpengaruh terhadap efektivitas pelaksanaan akuntansi pada UMKM (Y).

$\mathrm{H}_{1}: \beta_{\mathrm{i}}>0$ Pendidikan pemilik $\left(\mathrm{X}_{1}\right)$ dan pengalaman usaha $\left(\mathrm{X}_{2}\right)$, secara parsial berpengaruh terhadap efektivitas pelaksanaan akuntansi pada UMKM (Y).

Menguji hipotesis tersebut dengan mengunakan statistik t, yaitu dengan membanding-kan $t_{\text {hitung }}$ dengan $t_{\text {tabel }}$ pada $\alpha=0,05$ dan derajat bebas (n-k-1) adalah jumlah variabel independen dengan kriteria keputusan:

Jika $t_{\text {hitung }} \leq \mathrm{t}_{\text {tabel }}: \mathrm{H}_{\mathrm{o}}$ diterima atau $\mathrm{H}_{1}$ ditolak. Jika $t_{\text {hitung }}>t_{\text {tabel }}: \mathrm{H}_{1}$ diterima atau $\mathrm{H}_{\mathrm{o}}$ ditolak.

\section{HASIL DAN PEMBAHASAN}

\section{Karakteristik Responden}

Untuk mendapatkan data primer, peneliti menyebarkan kuesioner kepada para pemilik UMKM di Pasar Butung Makassar sebanyak 89 responden dengan karakteristik sebagai berikut:

\section{a. Jenis Kelamin}

Distribusi frekuensi responden berdasarkan jenis kelamin dapat dilihat pada tabel berikut:

Tabel 3

Karakteristik Responden Penelitian Berdasarkan Jenis Kelamin

\begin{tabular}{|c|l|c|c|}
\hline No. & Jenis Kelamin & Frekuensi & Persentase \\
\hline 1. & Pria & 47 & $52,8 \%$ \\
\hline
\end{tabular}




\begin{tabular}{|c|c|c|c|} 
2. & Wanita & 42 & $47,2 \%$ \\
\hline & Total & 89 & $100 \%$ \\
\hline
\end{tabular}

Sumber : Data Olahan 2017

Berdasar Tabel 3 terlihat sebagian besar pelaku UMKM adalah pria sebesar $52,8 \%$ dan $47,2 \%$ adalah wanita.

\section{b. Umur}

Distribusi frekuensi responden berdasarkan umur pemilik UMKM dapat dilihat pada tabel berikut:

Tabel 4.

Karakteristik Responden Penelitian Berdasarkan Umur

\begin{tabular}{|c|c|c|c|}
\hline No. & Umur & Frekuensi & Persentase \\
\hline 2. & $20-40$ Tahun & 56 & $62,9 \%$ \\
\hline 3. & $41-60$ Tahun & 29 & $32,6 \%$ \\
\hline 4. & $>60$ Tahun & 4 & $4,5 \%$ \\
\hline & Total & 89 & $100 \%$ \\
\hline
\end{tabular}

Sumber : Data Olahan 2017

Berdasar Tabel 4 terlihat bahwa pelaku UMKM yang berumur 20 - 40 sebesar $62,9 \%$, yang berumur $41-60$ sebesar 32,6\%. Sedangkan yang berumur 60 tahun keatas sebesar 4,5\% artinya pelaku UMKM masih didominasi oleh orang-orang yang berumur produktif yaitu 20 - 60 tahun.

\section{c. Tingkat Pendidikan}

Distribusi frekuensi responden berdasarkan pendidikan terakhir yang ditempuh pemilik UMKM dapat dilihat pada tabel berikut:

\section{Tabel 5.}

Karkateristik Responden Berdasarkan Tingkat Pendidikan

\begin{tabular}{|c|l|c|c|}
\hline No. & Pendidikan & Frekuensi & Persentase \\
\hline 1. & SD & 3 & $3,37 \%$ \\
\hline 2. & SMP & 13 & $14,61 \%$ \\
\hline 3. & SMA & 58 & $65,17 \%$ \\
\hline 4. & Diploma & 1 & $1,12 \%$ \\
\hline 5. & Sarjana & 14 & $15,73 \%$ \\
\hline \multicolumn{2}{|c|}{ Total } & 89 & $100 \%$ \\
\hline
\end{tabular}

Sumber : Data Olahan 2017

Berdasar Tabel 5 terlihat bahwa sebagian pelaku UMKM berpendidikan terakhir SMA yaitu sebesar $65,17 \%$ dan sarjana sebesar 15, 73\% selebihnya adalah SD dan SMP. Hal ini mengindikasikan bahwa pelaku UMKM adalah berpendidikan relatif rendah.

\section{Hasil Uji Statistik Deskriptif}

Hasil statistik deskriptif terhadap variabel dependen dan variabel independen pada penelitian ini disajikan pada tabel berikut: 
Tabel 6.

Hasil Uji Statitistik Deskriptif

\begin{tabular}{|l|c|c|c|c|c|}
\hline & $\mathbf{N}$ & $\begin{array}{c}\text { Minimu } \\
\mathbf{m}\end{array}$ & Maximum & Mean & Std. Deviation \\
\hline Pendidikan Pemilik & 89 & 1.00 & 5.00 & 3.0449 & .94038 \\
\hline Pengalaman Usaha & 89 & 1.00 & 5.00 & 4.2809 & 1.09740 \\
\hline $\begin{array}{l}\text { Efektivitas Pelaksanaan } \\
\text { Akuntansi }\end{array}$ & 89 & 16.00 & 63.00 & 31.1910 & 6.88687 \\
\hline Valid N (listwise) & 89 & & & & \\
\hline
\end{tabular}

Sumber : Data Olahan 2017

Berdasarkan Tabel 6 diatas, dapat diketahui bahwa variabel efektivitas pelaksanaan akuntansi $(\mathrm{Y})$ dengan jumlah data $(\mathrm{N})$ sebanyak 89 , memiliki nilai minimum sebesar 16,00, nilai maximum sebesar 63,00, nilai mean sebesar 31,1910 , dan nilai standar deviasi sebesar 6,88687. Variabel pendidikan pemilik (X1) dengan jumlah data $(\mathrm{N})$ sebanyak 89 , memiliki nilai minimum sebesar 1,00, nilai maximum sebesar 5,00, nilai mean sebesar 4,2809, dan nilai standar deviasi sebesar 6.88687. Sedangkan variabel pengalaman usaha (X2) dengan jumlah data (N) sebanyak 89, memiliki nilai minimum sebesar 1,00, nilai maximum sebesar 5,00, nilai mean sebesar 3,0449, dan nilai standar deviasi sebesar 0,94038.

\section{Uji Kualitas Data}

\section{a. Uji Validitas.}

Uji validitas digunakan untuk mengetahui ketepatan/kehandalan dalam butir pertanyaan dalam mendefinisikan suatu variabel. Pengujian validitas dari instrumen penelitian dilakukan dengan menghitung angka korelasional atau $R_{\text {hitung }}$ dari nilai jawaban tiap responden untuk tiap butir pertanyaan, kemudian dibandingkan dengan $\mathrm{R}_{\text {tabel }}$. Suatu instrumen (setiap butir pertanyaan) dikatakan valid bila angka korelasional yang diperoleh dari perhitungan lebih besar dengan $\mathrm{R}_{\text {tabel. }}$ Nilai $\mathrm{R}_{\text {tabel }}$ dilihat pada tabel $\mathrm{R}$ dengan $\mathrm{df}=\mathrm{n}-2 \quad(\mathrm{n}=$ jumlah responden/sampel), atau 89-2 = 87 dengan taraf signifikansi 5\%. Hasil uji validitas pertanyaan pada efektivitas pelaksanaan akuntansi disajikan pada tabel berikut:

Tabel 7.

Uji Validitas Efektivitas Pelaksanaan Akuntansi

\begin{tabular}{|c|c|c|c|}
\hline $\begin{array}{c}\text { No. } \\
\text { Pertanyaan }\end{array}$ & $\begin{array}{c}\text { Nilai R } \\
\text { Hitung }\end{array}$ & $\begin{array}{c}\text { Nilai R } \\
\text { Tabel }\end{array}$ & Kriteria \\
\hline 1 & 0,645 & 0,2084 & Valid \\
\hline 2 & 0,600 & 0,2084 & Valid \\
\hline 3 & 0,480 & 0,2084 & Valid \\
\hline 4 & 0,635 & 0,2084 & Valid \\
\hline 5 & 0,420 & 0,2084 & Valid \\
\hline 6 & 0,481 & 0,2084 & Valid \\
\hline 7 & 0,389 & 0,2084 & Valid \\
\hline 8 & 0,572 & 0,2084 & Valid \\
\hline 9 & 0,523 & 0,2084 & Valid \\
\hline 10 & 0,499 & 0,2084 & Valid \\
\hline
\end{tabular}




\begin{tabular}{|c|c|c|c|}
\hline 11 & 0,600 & 0,2084 & Valid \\
\hline 12 & 0,747 & 0,2084 & Valid \\
\hline 13 & 0,732 & 0,2084 & Valid \\
\hline 14 & 0,708 & 0,2084 & Valid \\
\hline 15 & 0,746 & 0,2084 & Valid \\
\hline 16 & 0,613 & 0,2084 & Valid \\
\hline
\end{tabular}

Sumber : Data Olahan 2017

Berdasarkan Tabel 7, di atas, dapat diketahui bahwa nilai $\mathrm{R}_{\text {tabel }}$ adalah sebesar 0,2084 . Dengan membandingkan antara nilai $R_{\text {hitung }}$ dan nilai $R_{\text {tabel }}$, maka diperoleh bahwa nilai $\mathrm{R}_{\text {hitung }}$ pada 16 butir pertanyaan adalah lebih besar daripada nilai $R_{\text {tabel }}(0,2084)$, atau nilai $R_{\text {hitung }}>$ nilai $R_{\text {tabel }}$. Dengan demikian, dapat disimpulkan bahwa sebanyak 16 butir pertanyaan pada variabel efektivitas pelaksanaan akuntansi tersebut telah valid.

\section{b. Uji Reliabilitas.}

Uji reliabilitas dimaksudkan untuk mengetahui apakah alat pengumpul data pada dasarnya menunjukkan tingkat ketepatan, keakuratan, kestabilan, atau konsistensi alat tersebut dalam mengungkapkan gejala tertentu dari sekelompok individu, walaupun dilakukan terhadap pernyataan-pernyataan yang sudah valid, untuk mengetahui sejauh-mana hasil pengukuran tetap konsisten bila dilakukan pengukuran kembali terhadap gejala yang sama.

Untuk menentukan butir-butir pertanyaan variabel reliabel atau tidak reliabel, digunakan perbandingan antara Cronbach's Alpha dengan alpha yang ditentukan sebelumya yaitu 0,60. Jika nilai Cronbach's Alpha>0,60 dikatakan reliabel dan jika nilai Cronbach's Alpha $<0,60$ dikatakan tidak reliabel (Sunyoto, 2012). Hasil uji reliabilitas pada variabel efektivitas pelaksanaan akuntansi disajikan pada tabel berikut:

\section{Tabel 8.}

Hasil Uji Reliabilitas

\begin{tabular}{|c|c|}
\hline Cronbach's Alpha & N of Items \\
\hline .871 & 16 \\
\hline
\end{tabular}

Sumber : Data Olahan 2017

Berdasarkan Tabel 8 di atas, dapat diketahui bahwa nilai Cronbach's Alpha yang diperoleh melalui perhitungan dengan menggunakan program SPPS 12 adalah sebesar 0,871. Dengan membandingkan antara nilai Cronbach's Alpha dengan nilai Alpha yang ditentukan sebelumya yaitu 0,60. Maka diperoleh bahwa nilai Cronbach's alpha $(0,871)$ lebih besar daripada nilai Alpha $(0,60)$, atau nilai Cronbach's Alpha > nilai Alpha. Dengan demikian, dapat disimpulkan bahwa variabel efektivitas pelaksanaan akuntansi tersebut telah reliabel.

\section{Penilaian Efektivitas} adalah:

Penilaian efektivitas pelaksanaan akuntansi pada UMKM di Makassar

$$
\text { Jumlah skor kriterium } \quad=5 \times 16 \times 89
$$




$$
\begin{aligned}
& =7120 \\
\text { Tingkat Persentase Efektivitas } & =\frac{2776}{7120} \times 100 \% \\
& =38,98 \% \text { (Dibulatkan menjadi 39\%) }
\end{aligned}
$$

Hal ini berarti tingkat efektivitas pelaksanaan akuntansi pada UMKM di Makassar adalah sebesar 39\%. Jika disesuaikan berdasarkan kategori penilaian efektivitas, maka efektivitas pelaksanaan akuntansi pada UMKM di Makassar tidak terlaksana dengan efektif, sebab nilai dari perhitungan tingkat persentase efektivitas kurang dari $40 \%$.

\section{Uji Asumsi Klasik}

\section{a. Uji Normalitas}

Untuk model regresi yang baik digunakan data yang terdistribusi normal atau mendekati normal. Data dikatakan terdistribusi normal apabila memenuhi asumsi normalitas data yaitu, data menyebar di sekitar garis diagonal dan mengikuti arah garis diagonal. Jika data menyebar jauh dari garis diagonal, maka model regresi dikatakan tidak memenuhi asumsi normalitas. Hasil pengujian normalitas disajikan pada gambar berikut.

Gambar 2

Hasil Uji Normalitas

Normal P-P Plot of Regression Standardized Residual

Dependent Variable: $Y$

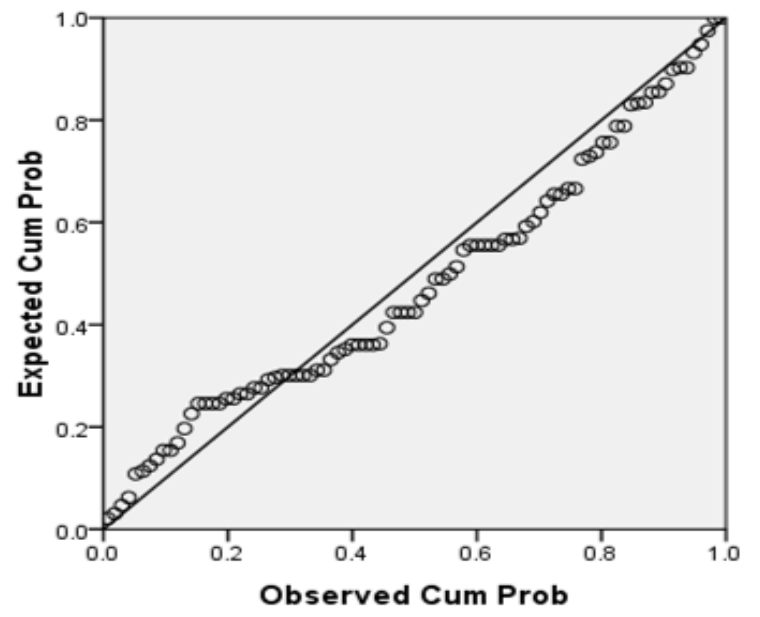

Berdasarkan kurva Regression Standardized Residual dapat diketahui bahwa garis kurva normal, berarti data yang diteliti juga normal. Selain itu, berdasarkan gambar Normal P-P Plot of Regression Standardized Residual di atas, dapat diketahui bahwa titik-titik menyebar dan mengikuti garis diagonal. Dengan demikian, variabel dependen dan variabel independen yang digunakan dalam penelitian ini telah berdistribusi normal.

\section{Uji Autokolerasi.}

Adanya autokorelasi dalam regresi dapat diketahui dengan uji Durbin Watson. Model regresi berganda ini akan terbebas dari autokorelasi jika nilai 
DWhitung mendekati angka dua. Hasil pengujian autokorelasi disajikan pada tabel berikut:

Tabel 9.

Hasil Uji Autokorelasi

\begin{tabular}{|c|c|}
\hline Model & Durbin-Watson \\
\hline 1 & 1.964 \\
\hline
\end{tabular}

a. Predictors: (Constant), Pengalaman Usaha, Pendidikan Pemilik

b. Dependent Variable: Efektivitas Pelaksanaan Akuntansi

Berdasarkan Tabel 9, di atas menunjukkan hasil bahwa nilai Durbin Watson (DW hitung) adalah sebesar 1,964. Berdasarkan kriteria yang telah ditentukan DW hitung berada diantara -2 dan 2 , yakni $-2 \leq 2 \leq 2$ atau mendekati angka dua, maka hal ini berarti tidak terjadi autokorelasi. Dengan demikian, dapat disimpulkan bahwa tidak terjadi gejala autokorelasi pada model regresi yang digunakan dalam penelitian ini.

\section{Uji Multikolinearitas.}

Uji multikolinearitas digunakan untuk menguji apakah ada korelasi antar variabel independen. Metode yang digunakan untuk mendeteksi adanya multikolinearitas adalah dengan menggunakan nilai VIF (Variance Inflation Factor). Jika nilai Tolerance value $>0,01$ dan atau VIF lebih kecil dari angka 10 (VIF < 10), maka hasil uji menunjukkan tidak terdapat gejala multikolinearitas atau kolerasi dengan variabel bebas lainnya. Hasil pengujian multikolinearitas disajikan pada tabel berikut:

Tabel 10.

Hasil Uji Multikolineraitas

\begin{tabular}{|l|c|c|}
\hline \multirow{2}{*}{ Model } & \multicolumn{2}{|c|}{ Collinearity Statistics } \\
\cline { 2 - 3 } & Tolerance & VIF \\
\hline $\begin{array}{l}\text { Pendidikan } \\
\text { Pemilik } \\
\begin{array}{l}\text { Pengalaman } \\
\text { Usaha }\end{array}\end{array}$ & .931 & 1.074 \\
\hline
\end{tabular}

a. Dependent Variable: Efektivitas Pelaksanaan Akuntansi

Berdasarkan hasil pengujian yang disajikan pada Tabel 10 tersebut, nilai VIF pada keseluruhan variabel independen (Pendidikan Pemilik dan Pengalaman Usaha) menghasilkan nilai Tolerance Value lebih dari 0,01 atau nilai VIF lebih kecil dari 10. Dengan demikian, hasil tersebut menunjukkan bahwa tidak terdapat gejala multikolinearitas antar variabel independen.

\section{Uji Heterokedastisitas.}

Adanya heteroskedastisitas dalam regresi dapat diketahui dengan menggunakan uji Glesjer dengan menggunakan taraf signifikansi 5\%. Jika variabel independen signifikan secara statitistik (lebih kecil dari $a=5 \%$ ) terhadap nilai residual yang diperlakukan sebagai variabel dependen, maka variabel independen tersebut menunjukkan adanya heteroskedastisitas. Hasil pengujian heterokedastisitas disajikan pada gambar dan tabel berikut : 


\section{Gambar 5}

Hasil Uji Heterokedastisitas

Scatterplot

Dependent Variable: $Y$

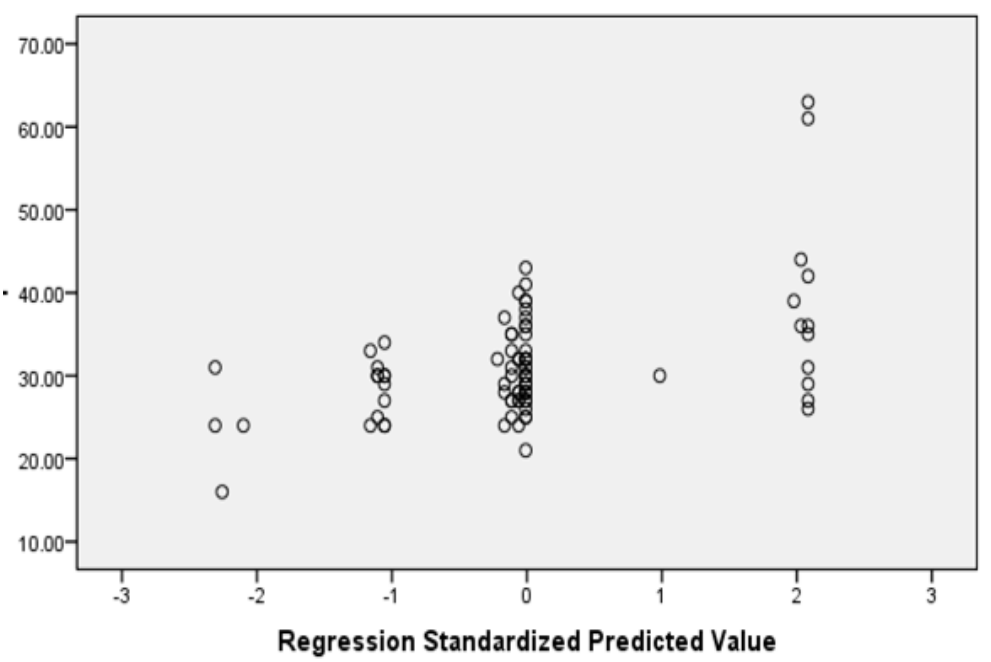

Berdasarkan hasil pengujian terhadap gejala heterokedastisitas pada gambar di atas, dapat diamati bahwa terdapat pola tertentu yang terbentuk dan titik-titik tidak menyebar secara merata. Hasil pengujian heterokedastisitas menggunakan uji Glesjer adalah sebagai berikut:

Tabel 11

Hasil Uji Heterodekastisitas

\begin{tabular}{|c|c|c|c|c|c|c|}
\hline \multirow{2}{*}{\multicolumn{2}{|c|}{ Model }} & \multicolumn{2}{|c|}{$\begin{array}{l}\text { Unstandardized } \\
\text { Coefficients }\end{array}$} & \multirow{2}{*}{ 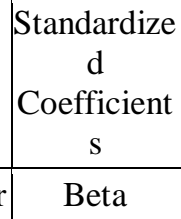 } & \multirow[b]{2}{*}{$\mathrm{T}$} & \multirow[b]{2}{*}{ Sig. } \\
\hline & & B & Std. Error & & & \\
\hline \multirow[t]{3}{*}{1} & (Constant) & 19.550 & 2.988 & & 6.544 & .000 \\
\hline & $\begin{array}{l}\text { Pendidikan } \\
\text { Pemilik }\end{array}$ & 3.572 & .711 & .488 & 5.026 & .000 \\
\hline & $\begin{array}{l}\text { Pengalaman } \\
\text { Usaha }\end{array}$ & .179 & .609 & .028 & .293 & .770 \\
\hline
\end{tabular}

a. Dependent Variable : Efektivitas Pelasaksanaan Akuntansi

Berdasarkan hasil perhitungan uji Glesjer yang ditampilkan pada Tabel 11 di atas menunjukkan bahwa terdapat gejala heteroskedastisitas yang terjadi dalam proses estimasi parameter model penduga. Hal ini dapat diketahui karena terdapat nilai signifikan (sig.) yang lebih kecil dari $0,05(p<0,05)$ sebesar 0.000 pada salah satu variabel independen, yaitu pendidikan pemilik. Dengan demikian, dapat disimpulkan bahwa secara keseluruhan terdapat gejala heteroskedastisitas pada model regresi yang digunakan dalam penelitian ini. 


\section{Hasil Uji Hipotesis}

\section{Koefisien Determinasi}

Untuk mengetahui besarnya hubungan antar variabel pendidikan pemilik dan pengalaman usaha terhadap efektivitas pelaksanaan akuntansi, maka dapat diketahui hasil perhitungan koefisien regresi (R) berdasarkan hasil perhitungan dengan menggunakan program SPSS 12 yang disajikan pada tabel koefisien determinasi berikut:

Tabel 12

Koefisien Determinasi

\begin{tabular}{|c|c|c|c|c|}
\hline Model & $\mathrm{R}$ & R Square & $\begin{array}{c}\text { Adjusted R } \\
\text { Square }\end{array}$ & $\begin{array}{c}\text { Std. Error of } \\
\text { the Estimate }\end{array}$ \\
\hline 1 & $.496^{\mathrm{a}}$ & .246 & .228 & 6.04921 \\
\hline
\end{tabular}

a. Predictors: (Constant), Pengalaman Usaha, Pendidikan Pemilik

b. Dependent Variable: Efektivitas Pelaksanaan Akuntansi

Berdasarkan Tabel 12 di atas, dapat diketahui bahwa nilai $\mathrm{R}$ sebesar 0,496 atau sebesar $49,6 \%$. Hal ini menunjukkan bahwa secara keseluruhan variabel independen yang terdiri dari pendidikan pemilik dan pengalaman usaha memiliki hubungan yang cukup kuat terhadap variabel dependennya yaitu efektivitas pelaksanaan akuntansi.

Nilai R Square sebesar 0,228 atau sebesar $22.8 \%$ menunjukkan bahwa variabel independen yang terdiri dari pendidikan pemilik dan pengalaman usaha memiliki pengaruh sebesar $22,8 \%$ terhadap variabel independen yaitu efektivitas pelaksanaan akuntansi. Sedangkan sisanya sebesar 77,2\% dipengaruhi oleh faktorfaktor lain yang tidak terdapat dalam penelitian ini.

\section{Analisis Regresi Linier Berganda}

Hasil analisis regresi linier berganda disajikan pada tabel berikut:

Tabel 13

Hasil Analisis Regresi Linier Berganda

\begin{tabular}{|l|r|r|}
\hline \multirow{2}{*}{\multicolumn{1}{|c|}{ Model }} & \multicolumn{2}{|c|}{ Unstandardized Coefficients } \\
\cline { 2 - 3 } 1 (Constant) & 19.550 & \multicolumn{1}{c|}{ Std. Error } \\
\hline $\begin{array}{l}\text { Pendidikan } \\
\text { Pemilik }\end{array}$ & 3.572 & .988 \\
$\begin{array}{l}\text { Pengalaman } \\
\text { Usaha }\end{array}$ & .179 & .609 \\
\hline
\end{tabular}

Maka diperoleh hasil persamaan regresi linier berganda sebagai berikut:

$$
\mathrm{Y}=\mathbf{1 9 . 5 5 0}+\mathbf{3 . 5 7 2} \mathrm{X} 1+\mathbf{0 , 1 7 9} \mathrm{X} 2+\mathrm{e}
$$

Interpretasi persamaan regresi linier berganda di atas adalah sebagai berikut:

a. Berdasarkan persamaan regresi linier berganda di atas, dapat diketahui bahwa nilai konstanta adalah sebesar 19,550 dan nilai koefisien regresi pada kedua variabel bebas yang terdiri dari pendidikan pemilik dan pengalaman usaha adalah positif. Artinya variabel efektivitas pelaksanaan akuntansi memiliki keterkaitan secara linier dengan pendidikan pemilik dan pengalaman usaha. 
b. Berdasarkan persamaan regresi linier berganda di atas, dapat diketahui bahwa nilai koefisien regresi pada variabel pendidikan pemilik adalah sebesar 3,572 dan nilai koefisien regresi adalah positif. Artinya hubungan variabel pendidikan pemilik (X1) memiliki hubungan yang searah dan sangat kuat dengan efektivitas pelaksanaan akuntansi (Y).

Berdasarkan persamaan regresi linier berganda di atas, dapat diketahui bahwa nilai koefisien regresi pada variabel pengalaman usaha adalah sebesar 0,179 dan nilai koefisien regresi adalah positif. Artinya hubungan variabel pengalaman usaha (X2) memiliki hubungan yang searah dan sangat lemah dengan efektivitas pelaksanaan akuntansi (Y).

\section{Uji Hipotesis}

\section{a. Pengujian Hipotesis Secara Simultan}

Pengujian hipotesis ini digunakan untuk mengetahui apakah pendidikan pemilik dan pengalaman usaha berpengaruh secara signifikan terhadap efektivitas pelaksanaan akuntansi pada UMKM di Makassar. Hasil uji hipotesis secara simultan disajikan pada tabel berikut:

Tabel 14.

Hasil Uji Hipotesis Secara Simultan

\begin{tabular}{|ll|r|r|r|c|c|}
\hline & Model & Sum of Squares & Df & Mean Square & F & Sig. \\
\hline 1 & Regression & 1026.755 & 2 & 513.378 & 14.029 & $.000^{\mathrm{a}}$ \\
& Residual & 3146.997 & 86 & 36.593 & & \\
& Total & 4173.753 & 88 & & & \\
\hline
\end{tabular}

a. Predictors: (Constant), Pengalaman Usaha, Pendidikan Pemilik

b. Dependent Variable: Efektivitas Pelaksanaan Akuntansi

Berdasarkan Tabel 14 di atas, dapat diketahui bahwa nilai dari $\mathrm{F}_{\text {hitung }}$ adalah sebesar 14,029 dan nilai signifikan (sig.) sebesar 0,000. Nilai $F_{\text {tabel }}$ dengan menggunakan tingkat signifikansi 0,05 adalah sebesar 1,4198. Dengan membandingkan antara nilai $F_{\text {hitung }}$ dan nilai $F_{\text {tabel }}$, maka diperoleh nilai Fhitung $(14,029)>$ nilai $F_{\text {tabel }}(1,4198)$, dan nilai sig. lebih kecil daripada 0,05 atau $0.000<0,05$. Dengan demikian, H1 diterima dan Ho ditolak. Maka dapat disimpulkan bahwa pendidikan pemilik dan pengalaman secara bersama-sama (simultan) berpengaruh positif dan signifikan terhadap efektivitas pelaksanaan akuntansi.

\section{b. Pengujian Hipotesis Secara Parsial}

Pengujian hipotesis secara parsial digunakan untuk mengetahui variabel manakah yang memberikan pengaruh paling dominan dari masing-masing variabel independen yang terdiri dari pendidikan pemilik dan pengalaman usaha terhadap variabel independen efektivitas pelaksanaan akuntansi. Hasil pengujian hipotesis secara parsial disajikan pada tabel berikut:

\section{Tabel 15}

\section{Hasil Uji Hipotesis Secara Parsial}

\begin{tabular}{|c|c|c|c|c|}
\hline & $\begin{array}{c}\text { Unstandardized } \\
\text { Coefficients }\end{array}$ & $\begin{array}{c}\text { Standardized } \\
\text { Coefficients }\end{array}$ & $\mathrm{T}$ & Sig. \\
\hline
\end{tabular}




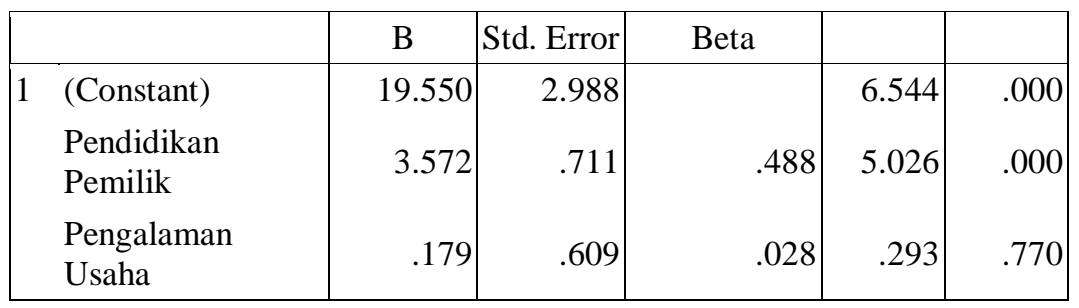

a. Dependent Variable: Efektivitas Pelaksanaan Akuntansi

Berdasarkan tabel 15 di atas, dapat diketahui hubungan masing-masing variabel independen terhadap variabel dependen efektivitas pelaksanaan akuntansi secara parsial.

- Pengaruh pendidikan pemilik terhadap efektivitas pelaksanaan akuntansi pada UMKM di Makassar. Berdasarkan hasil perhitungan dengan menggunakan program SPSS 12, dapat diketahui bahwa nilai dari $\mathrm{T}_{\text {hitung }}$ adalah sebesar 5,026 dan nilai signifikan (sig.) sebesar 0,000. Nilai $\mathrm{T}_{\text {tabel }}$ dengan menggunakan tingkat signifikansi 0,05 adalah sebesar 1,987. Dengan membandingkan antara nilai $\mathrm{T}_{\text {hitung }}$ dan nilai $\mathrm{T}_{\text {tabel }}$, maka diperoleh nilai $\mathrm{T}_{\text {hitung }}(5,026)>$ nilai $\mathrm{T}_{\text {tabel }}(1,987)$, dan nilai sig. lebih kecil daripada 0,05 atau $0.000<0,05$. Dengan demikian, H1 diterima dan Ho ditolak. Maka dapat disimpulkan bahwa pendidikan pemilik berpengaruh positif dan signifikan terhadap efektivitas pelaksanaan akuntansi pada UMKM di Makassar.

- Pengaruh pengalaman usaha terhadap efektivitas pelaksanaan akuntansi pada UMKM di Makassar. Berdasarkan hasil perhitungan dengan menggunakan program SPSS 12, dapat diketahui bahwa nilai dari $\mathrm{T}_{\text {hitung }}$ adalah sebesar 0,293 dan nilai signifikan (sig.) sebesar 0,770. Nilai $\mathrm{T}_{\text {tabel }}$ dengan menggunakan tingkat signifikansi 0,05 adalah sebesar 1,987. Dengan membandingkan antara nilai $\mathrm{T}_{\text {hitung }}$ dan nilai $\mathrm{T}_{\text {tabel }}$, maka diperoleh nilai $\mathrm{T}_{\text {hitung }}(0,293)<$ nilai $\mathrm{T}_{\text {tabel }}(1,987)$, dan nilai sig. lebih besar daripada 0,05 , atau $0.770>0,05$. Dengan demikian, $\mathrm{H}_{0}$ diterima dan $\mathrm{H}_{1}$ ditolak. Maka dapat disimpulkan bahwa pengalaman usaha berpengaruh positif dan tidak signifikan terhadap efektvitas pelaksanaan akuntansi pada UMKM di Makassar.

\section{PEMBAHASAN}

\section{Pengaruh Pendidikan Pemilik terhadap Efektivitas Pelaksanaan Akuntansi}

Pendidikan pemilik dan pengalaman usaha secara bersama-sama berpengaruh terhadap efektivitas pelaksanaan akuntansi pada UMKM di Makassar, artinya pendidikan pemilik jika dibarengi dengan pengalaman usaha akan berpengaruh terhadap efektivitas penerapan akuntansi pada UMKM di Makassar. Ini menunjukkan bahwa hal-hal yang menyangkut pengalaman menangani usaha akan memberikan pengetahuan yang memudahkan pemilik usaha untuk melaksanakan pencatatan akuntansi.

Begitu pula tingkat pendidikan yang dimiliki oleh pemilik usaha akan memberikan pemahaman dari esensi suatu pencatatan dari berusaha, sehingga aktivitas transaksi yang terjadi dalam usaha dapat dipertanggungjawabkan, serta 
menjadi media untuk menilai kinerja usaha. Hal ini sejalan dengan penelitian sebelumnya, bahwa masa memimpin, pendidikan manajer atau pemilik, pelatihan akuntansi yamg diikuti manajer atau pemilik serta umur perusahaan berpengaruh terhadap penyiapan dan penggunaan informasi akuntansi pada perusahaan kecil dan menengah.

Pengaruh pendidikan pemilik terhadap efektivitas pelaksanaan akuntansi pada UMKM di Makassar, menunjukkan bahwa pendidikan berkontribusi untuk mengharuskan pelaksanaan pencatatan akuntansi, karena dengan pendidikan, pemilik memiliki pengetahuan normatif bahwa bahwa proses bisnis perlu di rekam supaya setiap transaksi yang terjadi dapat dipertanggungjawabkan dan dievaluasi sejauh mana transaksi ini memberikan efek positif (menguntungkan) bagi usaha, yang tentu berbeda dengan pengusaha yang memiliki tingkat pendidikan yang rendah, dimana hanya menjalankan bisnis secara konvensional. Mereka tidak memiliki pengetahuan yang cukup tentang informasi, pengambilan keputusan begitu pula pengendalian.

Kemampuan dan keahlian pemilik atau manajer perusahaan ini sangat mempengaruhi penyiapan dan penggunaan informasi akuntansi. Kemampuan dan keahlian pemilik atau manajer perusahaan sangat ditentukan oleh pendidikan formal yang telah ditempuh. Ini disebabkan karena perusahaan kecil dan menengah relatif tidak mampu menggunakan tenaga professional akuntansi (akuntan) baik sebagai tenaga kerja perusahaan maupun sebagai pemberi jasa akuntansi.

\section{Pengaruh Pengalaman Usaha terhadap Efektivitas Pelaksanaan Akuntansi}

Pengalaman usaha berpengaruh terhadap efektivitas pelaksanaan akuntansi pada UMKM di Makassar, menunjukkan bahwa pengalaman usaha memberikan kontribusi kepada pemilik untuk melaksanakan pencatatan akuntansi atas kegiatan bisnisnya. Pengalaman ini juga memberikan makna pengetahuan atas apa yang telah dan biasa terjadi berkaitan dengan bisnis. Pengalaman ini selalu memberikan petunjuk mengenai karakteristik transaksi dan fenomena bisnis yang selalu memberikan pengaruh terhadap kelangsungan usaha. Namun tidak signifikan untuk mengharuskan pemilik untuk melakukan pencatatan akuntansi karena tidak berbasis pengetahuan normatif.

Sejalan dengan penelitian Holmes (1989) memperlihatkan bahwa penerapan sistem akuntansi dipengaruhi oleh usia/pengalaman usaha. Hasil penelitian itu menyatakan bahwa perusahaan yang berdiri selama 10 tahun atau kurang, menyediakan lebih banyak informasi akuntansi statutory, informasi akuntansi anggaran, informasi akuntansi tambahan untuk digunakan dalam pengambilan keputusan, berbeda dengan perusahaan yang berdiri selama 11-20 tahun.

\section{PENUTUP}

\section{Kesimpulan}

Dari pembahasan yang telah diuraikan, dpaat disimpulkan bahwa :

1. Pendidikan dan pengalaman pemilik tidak bisa dipisahkan untuk mengefektifkan pelaksanaan pencatatan akuntansi. Pendidikan yang dimiliki oleh pemilik usaha, memberikan pengetahuan jalannya bisnis secara normatif. 
Jika dibarengi dengan pengalaman bisnis, maka pengetahuan pemilik mengenai situasi bisnis semakin luas sehingga dorongan untuk melaksanakan kegiatan akuntansi semakin penting.

2. Pelaksanaan akuntansi untuk pelaku bisnis UMKM, menunjukkan belum efektivitas pelaksanaan akuntansi, karena memang komunitas pelaksana bisnis sektor ini dilakukan oleh masyarakat berpendidikan bawah, dan melaksanakan bisnis dengan pendekatan konvensional.

3. Pendidikan pemilik berkontribusi terhadap efektivitas pelaksanaan akuntansi pada usaha UMKM, karena dengan pendidikan, mereka memiliki pengatahuan normatif yang memberikan petunjuk bahwa berbisnis itu perlu pertanggungjawaban sehingga perusahaan bisa dievaluasi untuk mencapai kelangsungan usaha.

4. Pengalaman usaha juga berkontribusi terhadap pelaksanaan praktik akuntansi, namun tidak signifikan karena pengalaman hanya memberikan pengetahuan akan hal-hal yang biasa alami oleh usaha, namun tidak memberikan keharusan karena pengetahuan normatif tidak mendalam secara teoritis.

\section{Saran}

1. Kurangnya pemahaman mengenai akuntansi dan pentingnya pelaksanaan akuntansi pada pelaku usaha kecil dan menengah, membuat mereka tidak menerapkan akuntansi pada usaha yang mereka rintis. Oleh sebab itu, diperlukan adanya penyuluhan dan memberikan pemahaman tentang akuntansi kepada pelaku UMKM, baik dari pihak akademisi maupun pihak lainnya yang berkecimpung dibidang akuntansi.

2. Untuk peneliti selanjutnya diharapkan dapat menambahkan beberapa variabel independen yang tidak terdapat dalam penelitian ini.

\section{DAFTAR PUSTAKA}

Arfan Ikhsan dan Muhammad Ishak. 2011. Akuntansi Keperilakuan. Jakarta: Salemba Empat.

Belkoui, Riahi, Ahmed. 2006. Accounting Theory, Buku Satu, Edisi 5. Jakarta : Salemba Empat.

Dewi Septiana Puji Astuti. 2010. Perlunya Penerapan Sistem Akuntansi Pada Usaha Kecil Menengah. Jurnal Ekonomi dan Kewirausahaan Vol. 12, No, 2.

Era Astuti, 2007. Pengaruh Karakteristik Internal Perusahaan Terhadap Penyiapan Dan Penggunaan Informasi Akuntansi Perusahaan Kecil Menengah. Tesis. UNDIP Semarang.

Grace, Solovida. 2003. “ Analisis Faktor-Faktor Yang Mempengaruhi Penyiapan dan Penggunaan Informasi Akuntansi Pada Perusahaan Kecil dan Menengah di Jawa Tengah" . Tesis. Semarang : Magister Akuntansi UNDIP

Holmes, Scott, Nicholls. 1989. An Analysis Of The Use Of Accounting Information By Australian Small Busines. Journal of Small Business Management.

Imam Ghozali,. 2009. Aplikasi Analisis Multivariate Dengan Program SPSS, Cetakan Keempat. Badan Penerbit Universitas Diponegoro; Semarang. 
Muhammad Wahyudi,. 2009. Faktor-Faktor Yang Mempengaruhi Akuntansi Pada Usaha Kecil dan Menengah (UMKM) di Yogyakarta. Skripsi Diterbitkan. Universitas Diponegoro.

Murniati. 2005. Investigasi Faktor-Faktor Yang Mempengaruhi Penyiapan dan Penggunaan Informasi Akuntansi Perusahaan Kecil dan Menengah. Semarang : SNA 5.

Nur Indriantoro, Bambang Supomo,. 2002. Metodologi Penelitian Bisnis Untuk Akuntansi dan Manajemen. BPFE; Yogyakarta.

Pratiwi Sarningtyas, Tituk Diah W., 2011. Standar Akuntansi Keuangan Entitas Tanpa Akuntabilitas Publik Pada Usaha Kecil Menengah. JAKI Vol. 1No. 1 Hal. 90-101. Jakarta.

Suwardjono, 2005. Teori Akuntansi, BPFE, Yogyakarta.

Warren, Carl S., dkk. 2014. Pengantar Akuntansi Adaptasi Indonesia. Salemba Empat; Jakarta.

Warsono, S. E. Murti, A. Ridha, D. A.Darmawan, 2010. Akuntansi UMKM Ternyata Mudah Dipahami dan Dipraktikkan, Asgard Chapter. Yogyakarta. 